Available online on $15.07 .2020 \mathrm{at} \mathrm{http://jddtonline.info}$
pelivery

Open Access to Pharmaceutical and Medical Research

(C) 2011-20, publisher and licensee JDDT, This is an Open Access article which permits unrestricted non-commercial use, provided the original work is properly cited

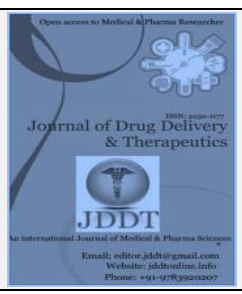

Open ${ }_{\text {Access }}$

\title{
Diabetes Insipedes in a child disclosing localized Langerhans' Cell Histiocytosis
}

\author{
Kamel El-Reshaid *, Shaikha Al-Bader **, Zaneta Markova *** \\ * Department of Medicine, Faculty of Medicine, Kuwait University \\ ** Department of Medicine, Nephrology Unit, Amiri Hospital, Ministry of health, Kuwait \\ *** Radiology Unit, IMC, Kuwait
}

\begin{abstract}
Langerhans cell histiocytosis (LCH) is monoclonal neoplastic condition of aberrant bone marrow histiocytes. The latter are part of the innate immune system and certain exogenous/endogenous stimuli may trigger its expansion. Hence LCH can present with limited or multiple organ involvement that may include; bones, lung, endocrine, skin, lymph nodes, spleen and bone marrow. In this case report, we describe a 3-year-old boy who presented with severe polyuria and polydipsia. Laboratory investigations were consistent with diabetes insipidus (DI). MRI of the brain; confirmed absence of the bright spot in his pituitary gland did not show evidence of tumor or enlargement by inflammation. Moreover, MRI revealed 2 skull lesions and their subsequent biopsy confirmed LCH. Systemic examination and tests including PET scan did not show additional lesions. Since his disease was localized, he received only Desmopressin acetate 120 ug twice daily for his DI without surgery, radiotherapy or chemotherapy. One year later, his disease remained limited to DI and the 2 bonny lesions.
\end{abstract}

Keywords: bone, diabetes insipidus, pituitary, desmopressin, Langerhans cell histiocytosis.

Article Info: Received 27 April 2020; Review Completed 24 June 2020; Accepted 04 July 2020; Available online 15 July 2020

Cite this article as:

El-Reshaid K, Al-Bader S, Markova Z, Diabetes Insipedes in a child disclosing localized Langerhans' Cell Histiocytosis, Journal of Drug Delivery and Therapeutics. 2020; 10(4):213-215 http://dx.doi.org/10.22270/jddt.v10i4.4181

*Address for Correspondence: Dr. Kamel El-Reshaid. Professor, Dept. of Medicine, Faculty of Medicine, Kuwait University, PO Box 24923, 13110 Safat, Kuwait

\section{INTRODUCTION}

Diabetes insipidus (DI) is a disorder characterized by polydipsia and polyuria due to lack or ineffective antidiuretic hormone $(\mathrm{ADH})$. The latter is produced by the hypothalamus and is stored in posterior lobe of pituitary gland (PG) ${ }^{1}$. ADH is released, if serum hyperosmolality is sensed by the hypothalamus, to prevent urinary water loss ${ }^{2}$. Hence, the disorder can result from; (a) cranial (PG/hypothalamus) disease and (b) nephrogenic resistance to its action. The most common causes of cranial DI are; (a) idiopathic (30\%), (b) malignant or benign tumors of the brain or PG (25\%), (c) cranial surgery $(20 \%)$, and head trauma $(16 \%)$. Rare etiologies include; genetic familial disorders, toxins, infections, sarcoidosis, hemochromatosis, amyloidosis, autoimmune hypophysitis and Langerhans cell histiocytosis $(\mathrm{LCH})^{3}$. The latter is an extremely rare neoplastic disorder of tissue histiocytes with variable phenotypic presentation from localized disease to an overwhelming malignant disease 4. In this case report, we describe a patient presenting with DI and localized bonny lesions and highlight his management.

\section{CASE REPORT:}

A 3-year-boy presented with history of excessive thirst and urination including wetting his bed at night for 1 year. The patient did not have past history of significant medical illness, allergy or chronic intake of medications. He did not ISSN: 2250-1177 [213] have similar problem in his family members. His initial physical examination did not show abnormality. Laboratory tests showed normal peripheral leucocytic and platelets counts. Hemoglobin was normal at $120 \mathrm{~g} / \mathrm{L}$. Serum sugar, urea, creatinine, electrolytes and liver functions were normal. Urine routine and microscopy did not show abnormality. Chest x-ray and ECG were normal. Ultrasound of the abdomen and pelvis was normal. His 24-hour urine volume was 6 liters. Night serum osmolality was 310 mmol/L (N: 275-290) with urine osmolality at $100 \mathrm{mmol} / \mathrm{L}$. He could not tolerate water overnight water restriction for polydipsia. Early morning ADH level was undetectable $(\mathrm{N}$ : 0.9 to $4.6 \mathrm{pmol} / \mathrm{L}$ ). Tests of the function of anterior PG function showed normal results. They included; insulin hypoglycemia for stimulation of growth hormone, TSH, T3, T4, 8 AM serum cortisol, FSH, LH, testosterone and prolactin. Moreover, he had normal levels of renin and aldosterone. MRI of the brain showed normal-sized pituitary gland and its stalk yet with abscent posterior pituitary bright spot on preenhanced T1W1 images (Fig. 1). In addition; MRI showed 2 soft tissue skull-based lesions, in the right frontoparietal and left occipital regions, which enhanced on contrast study (Fig. 2 ). Biopsy of the occipital lesion revealed large histiocytes with reniform and grooved nuclei with indistinct nucleoli and eosinophilic cytoplasm scattered among an infiltrate of lymphocytes, eosinophils, and macrophages (Fig. 3). On special stains, those large histiocytes were immunoreactive for antibodies directed against CD1a and S100 protein 
confirming LCH 5. PET-CT scan did not show additional lesions. He was treated with Minerin melt 120 ug twice daily. Within few days, he showed significant improvement in his thirst, appetite, enuresis, activity and had gained adequate weight. One week later; 24 hour urine volume as well as serum and urine osmolality were normal. Since his
DI was controlled and his bonny lesions were small and limited; he was not subjected to surgical excision of lesions, radiotherapy or chemotherapy. One year later; he remained stable while on Minirin melt. PET-CT scan did not show new bonny lesions or expansion of the previous ones.
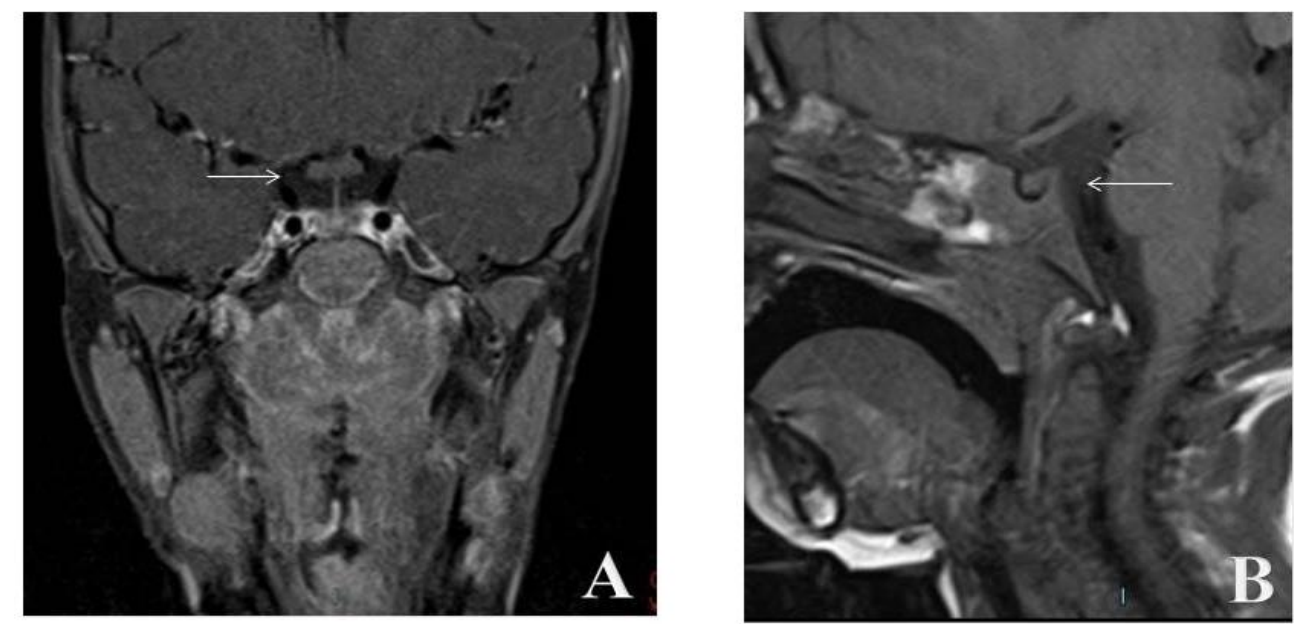

Figure 1: Pre-contrast coronal T1-weighted MRI view showing normal size of the pituitary gland and its stalk (A). Note absence of posterior pituitary bright spot in sagittal view (B).
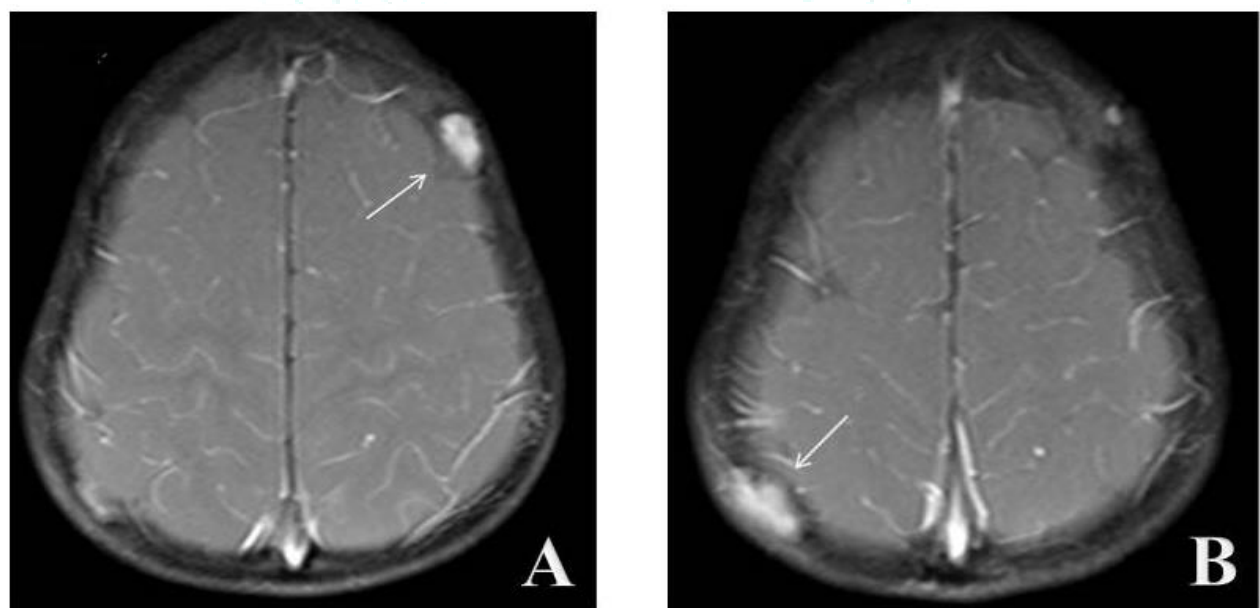

Figure 2: Axial Views of MRI of brain T1FS+CFC showing contrast enhancing skull lesions in the (A) right fronto-parietal and (B) left occipital areas.

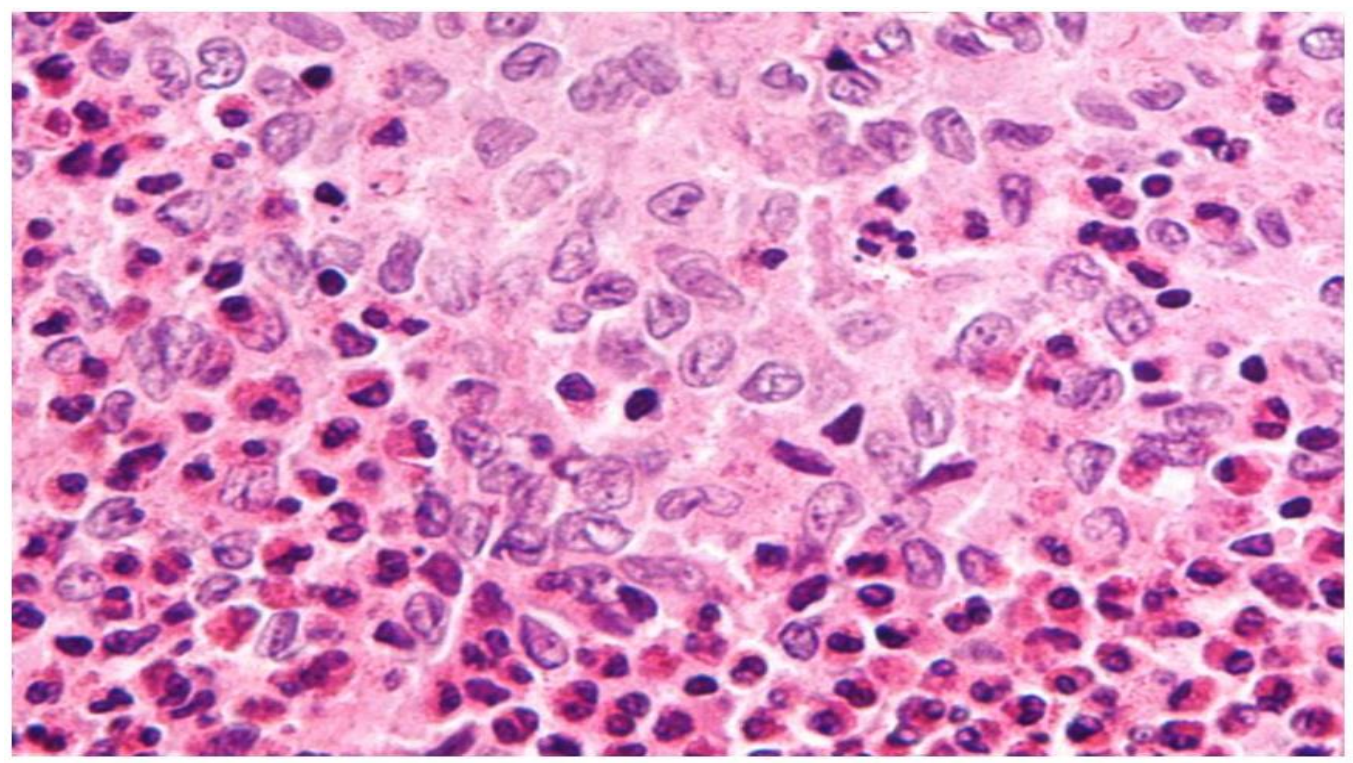

Figure 3: Photomicrograph of the bonny lesion showing large histiocytes with reniform and grooved nuclei with indistinct nucleoli and eosinophilic cytoplasm scattered among an infiltrate of lymphocytes, eosinophils, and macrophages (H\&E X 400). 


\section{DISCUSSION}

Our patient presented with polyuria with low urine osmolality and high serum osmolality indicating DI. The high serum osmolality excluded primary (psychogenic) polydipsia 6. Moreover, undetectable ADH and correction of polyuria, serum and urine osmolality after Desmopressin therapy confirmed diagnosis of cranial DI 7 . In search for the etiology of cranial DI; MRI was done. In our patient, it confirmed; the abscence of the "bright spot" which correlates with the secretory granules in the posterior lobe and ruled out abnormalities in the PG and its stalk induced by tumors and hypophysitis ${ }^{8}$. Moreover, MRI revealed 2 incidental soft tissue masses in his skull. Biopsy of the occipital one disclosed LCH and ruled out bonny metastasis. LCH is a rare disease arising from immature myeloid dendritic cells in the bone marrow rather than from epidermal Langerhans cells. Evidence of its monoclonicity was reported more than 20 years ago, supporting the notion that LCH is a neoplastic process 9. More recently, the identification of oncogenic BRAF V600E mutations in $25 \%$ to $64 \%$ of cases of LCH has provided additional evidence that LCH is a neoplasm 10. It occurs most often in children and in white individuals of northern European ancestry 4. The broad clinical spectrum that is encompassed by LCH is reflected in the many synonyms for this disease, which include eosinophilic granuloma (unifocal LCH), Hand-Shüller-Christian disease (multifocal unisystem LCH), and Letterer-Siwe disease (disseminated multifocal multisystem LCH). In singlesystem LCH, bone is the most common site of involvement followed by skin, lymph node, spleen, bone marrow and lung 4. Pulmonary LCH seems to be a distinct entity, as it occurs almost exclusively in smokers and may resolve with cessation of smoking ${ }^{11}$. Liver, spleen, and bone marrow are considered "risk organs involvement" and are associated with high risk of mortality ${ }^{4}$. Management of LCH is tailored to match the sites of involvement and extent of disease. Such strategy was based on the concept of disease induction and progression in relation to exogenous/endogenous stimuli since histiocytes are part of innate immunity system. For treatment purposes, patients with $\mathrm{LCH}$ are generally stratified into; (a) single-system or multisystem, and (b) high or low-risk organ involvement 12 . Chemotherapy for patients with low-risk multisystem LCH is 1 year of vinblastine and prednisone compared to an additional mercaptopurine in the high-risk group. On the other hand; children with bonny lesions rarely need more than curettage and may even regress spontaneously ${ }^{13}$. Our patient had central DI which is the most frequent CNS manifestation of $\mathrm{LCH}$, occurring in $10-50 \%$ of all patients 14 . However, and on follow up; 30$58 \%$ of those patients manifest anterior pituitary hormone deficiencies which seems to be linked to a thickening of the pituitary stalk 15. Moreover, they can also develop neurodegenerative disease ${ }^{16}$. Our patient had cranial DI and 2 skull lesions. His physical examination, laboratory investigations, radiological and PET scans did not show evidence of other systemic disease. Since he had limited disease; we elected to treat him conservatively and avoid chemotherapy. Fortunately, and after 1 year of follow up; he did not manifest further expansion of his disease.

\section{REFERRENCES:}

1. Maghnie M, Cosi G, Genovese E, et al. Central diabetes insipidus in children and young adults. N Engl J Med 2000; 343:998-1007.

2. Bourque CW. Central mechanisms of osmosensation and systemic osmoregulation. Nature Reviews. Neuroscience 2008; 9: 519-531.

3. Pablo S, Tipton GA, Chan JC. Diabetes insipidus. Pediatr Rev 2000; 21:122-129.

4. Jaffe R, Weiss LM, Facchetti F. Tumours derived from Langerhans cells. In: Swerdlow SH, Campo E, Harris NL, et al, eds. WHO Classification of Tumours of Haematopoietic and Lymphoid Tissues. 4th ed.Lyon, France: IARC Press; 2008:358-360. World Health Organization Classification of Tumours; vol 2.

5. Charles M. Harmon and Noah Brown. Langerhans Cell Histiocytosis: A Clinicopathologic Review and Molecular Pathogenetic Update. Arch Pathol Lab Med 2015; 139:12111214.

6. Psychogenic polydipsia-Management-Step by step. British Medical Journal. 5 May 2016.

7. Ghirardello S, Garre ML, Rossi A, Maghnie M: The diagnosis of children with central diabetes insipidus. J Pediatr Endocrinol Metab 2007; 20: 359-375.

8. Lucas JW, Zada G. Imaging of the pituitary and parasellar region. Semin Neurol 2012; 32:320-331.

9. Yu RC, Chu C, Buluwela L, Chu AC. Clonal proliferation of Langerhans cells in Langerhans cell histiocytosis. Lancet 1994; 343:767-768.

10. Badalian-Very G, Vergilio JA, Degar BA, et al. Recurrent BRAF mutations in Langerhans cell histiocytosis. Blood 2010; 116:1919-1923.

11. Roden AC, Hu X, Kip S, et al. BRAF V600E expression in Langerhans cell histiocytosis: clinical and immunohistochemical study on 25 pulmonary and 54 extrapulmonary cases. Am J Surg Pathol 2014; 38:548-551.

12. Degar BA, Fleming MD, Rollins BJ, Rodriguez-Galindo C. Histiocytoses. In: Orkin SH, Fisher DE, Ginsburg D, Look AT, Lux SE, Nathan DG, eds. Nathan and Oski's Hematology and Oncology of Infancy and Childhood. 8th ed. Philadelphia, PA: Elsevier Saunders; 2015; 2100-2122.

13. Minkov M. Multisystem Langerhans cell histiocytosis in children: current treatment and future directions. Paediatr Drugs 2011; 13: 75-86.

14. Grois N, Potschger U, Prosch H, Minkov M, Arico M, Braier J, Henter JI, Janka-Schaub G, Ladisch S, Ritter J, Steiner M, Unger E, Gadner H: Risk factors for diabetes insipidus in Langerhans cell histiocytosis. Pediatr Blood Cancer 2006; 46:228-233.

15. Grois N, Prayer D, Prosch H, et al. Course and clinical impact of magnetic resonance imaging findings in diabetes insipidus associated with Langerhans cell histiocytosis. Pediatr Blood Cancer 2004; 43:59-65.

16. Imashuku S, Shioda Y, Kobayashi R, et al. Neurodegenerative central nervous system disease as late sequelae of Langerhans cell histiocytosis. Report from the Japan LCH Study Group. Haematologica 2008; 93:615-618. 